\title{
ANALISIS KELAYAKAN DAN STRATEGI PENGEMBANGAN WILAYAH DALAM WACANA PEMBENTUKAN DAERAH OTONOM BARU BOGOR TIMUR
}

\author{
Feasibility Analysis and Regional Development Strategy on Discourse \\ of Regional Proliferation East Bogor
}

\author{
Aan Nurhasanah ${ }^{1}$, Bambang Juanda², Eka Intan Kumala Putri ${ }^{3}$
}

Diterima : 6 Juli 2017 Disetujui: 6 November 2017

\begin{abstract}
Abstrak: Kabupaten Bogor sebagai salah satu kabupaten yang memiliki wilayah yang luas dan jumlah penduduk yang besar memiliki banyak permasalahan terkait aksesibilitas dan pemerataan kesejahteraan. Pemekaran dianggap sebagai sebuah cara untuk mengatasi permasalahan tersebut. Penelitian menggunakan analisis skoring berdasarkan pp no.78 tahun 2007, analissi derajat otonomi fiskal, analisis location quotien (lq), tipologi klassen dan analisis swot secara deskriptif. Penelitian ini bertujuan untuk mengetahui kelayakan pemekaran wilayah bogor timur dan menyusun strategi pengembangan wilayah. Secara umum bogor timur layak untuk menjadi sebuah daerah otonom. Potensi ekonomi dan kemampuan fiskal yang tinggi dapat dijadikan sebagai dasar rekomendasi untuk menjadikan bogor timur sebagai sebuah daerah otonom. Adapun strategi yang dapat digunakan adalah bagaimana mengembangkan daerah yang relatif tertinggal berdasarkan sektor unggulannya, mendukung pengembangan sektor primer, misalnya pertanian. Kebijakan pemerintah sangat penting untuk mengoptimalkan pengelolaan sumberdaya, pemerataan pembangunan infrastruktur terutama untuk mendukung pembangunan di wilayah perdesaan. Implikasi dari kebijakan yang diterapkan berdasarkan karakter masing-masing wilayah seperti sosial buadaya, spasial dan sektor basis, ke depan pembangunan wilayah dapat dianalisis berdasarkan wilayah kecamatan.
\end{abstract}

Kata kunci : pemekaran wilayah, pengembangan wilayah, potensi ekonomi

\begin{abstract}
Bogor District as one of large region and large number of population has any problems related to accesibility and equity welfare. Regional proliferation considered as a way to overcome that problems. The study used scoring method based on PP no. 782007 with descriptive analysis, location quotient analysis, and Klassen Tiphology. This study was aimed to analyzed feasibility of regional proliferation and to formulate regional development strategy based on economic potentials in eastern Bogor District region. In general the result showed that eastern Bogor District region appropriate to organize as an autonomous region. High economic potential and fiscal cappacity of eastern Bogor region can be made as main factor to recommended eastern Bogor District region as an autonomous region. Thus, the selected strategies are how to develop backward regions base on leading sector, support primary sector development such as agricultural. Goverment policy is important to optimize natural resources

\footnotetext{
${ }^{1}$ Program Studi Ilmu Perencanaan Pembangunan Wilayah dan Perdesaan Institut Pertanian Bogor

${ }^{2}$ Departemen Ilmu Ekonomi, Fakultas Ekonomi dan Manajemen, Institut Pertanian Bogor

${ }^{3}$ Departemen Ekonomi Sumberdaya dan Lingkungan, Fakultas Ekonomi dan Manajemen, Institut Pertanian Bogor
} 
management, spread out infrastructure development mainly to support rural area development. The implication of policy directed base on each region characters such as social, culture, spatial, basic sector. Furthermore regional development analysis can be set base on sub-district region.

Keywords : regional development, regional proliferation, economic potential

\section{PENDAHULUAN}

Fenomena pembentukan daerah otonomi baru (DOB) di Indonesia telah menjadi fenomena yang menarik sejak disahkannya UU No. 22 Tahun 1999 mengenai Pemerintahan Daerah yang membuka keran bagi pembentukan daerah otonom baru. Berdasarkan data dari Direktorat Penataan Daerah, Otonomi Khusus dan Dewan Pertimbangan Otonomi Daerah Direktorat Jenderal Otonomi Daerah Kementerian Dalam Negeri (2014), sejak tahun 1999 setelah diberlakukannya UU No.22 Tahun 2009 sampai dengan tahun 2014 terdapat 34 propinsi, 415 kabupaten, dan 93 kota di Indonesia. Meningkat cukup signifikan daripada sebelum tahun 1999 yang hanya terdiri dari 26 Provinsi, 236 kabupaten dan 59 kota.

Sebagai daerah dengan luas wilayah dan jumlah penduduk yang cukup besar, Kabupaten Bogor memiliki permasalahan yang cukup kompleks dalam hal rentang kendali dan penyebaran pembangunan. Kesenjangan pembangunan akibat pertumbuhan ekonomi di sejumlah kawasan menimbulkan persoalan-persoalan kesejahteraan. Seperti di daerah lain pada umumya, yang melatarbelakangi pembentukan DOB Bogor Timur adalah percepatan pembangunan yang dilandasi kenginan untuk meningkatkan kesejahteraan rakyat, memperbaiki pelayanan publik, meningkatkan daya saing daerah, dan mewujudkan tata pemerintahan yang baik.

Menurut Susanti (2014), pemekaran daerah dalam arti pembentukan kabupaten dan kota, hendaknya juga ditujukan untuk memacu terbentuknya pusat-pusat pertumbuhan ekonomi baru yang akan membawa dampak pada peningkatan pendapatan dan kesejahteraan masyarakat, memperpendek jalur birokrasi, memperpendek rentang kendali, juga memberikan kemungkinan terbukanya isolasi-isolasi daerah yang terpencil. Pemekaran daerah merupakan suatu strategi yang dapat dilakukan ketika wilayah pelayanan telah menjadi terlalu luas, sehingga pemerintah tidak bisa optimal melaksanakan tugas-tugasnya termasuk dalam rangka pelayanan publik kepada masyarakat secara baik.

Otonomi daerah merupakan kebijakan desentralisasi yang dilakukan oleh pemerintah pusat (Supriyadi et al, 2013). Desentralisasi menyangkut penyerahan wewenang dalam pengelolaan keuangan daerah, sehingga desentralisasi fiskal adalah konsekuensi lain dari otonomi daerah. Menurut Wardhana et al (2013), pada era desentralisasi ini pemerintah pusat memberikan dana transfer kepada pemerintah daerah. Dana transfer pusat digunakan untuk menstimulus fiskal untuk daerah dalam meningkatkan pembangunannya. Dana transfer pusat yang berfungsi sebagai penyeimbangan keuangan antar daerah dan peningkatan pembangunan melalui Dana Alokasi Umum (DAU) dan Dana Alokasi Khusus (DAK).

Kabupaten Bogor merupakan daerah yang memiliki potensi yang tinggi pada sektor industri. Selain itu, dengan keadaan alam yang dimilikinya Bogor Timur sangat memungkinkan untuk pengembangan kegiatan yang berbasis pertanian. Berdasarkan data BPS tahun 2014 Proporsi produksi padi sawah calon DOB Kabupaten Bogor Timur sebesar $31 \%$ terhadap total produksi padi sawah di Kabupaten Bogor. Dalam konteks pembangunan wilayah, pembangunan sektor pertanian dan wilayah perdesaan sangat penting (Rustiadi et al, 2003). Karena apabila pembangunan sektor ini disuatu wilayah tidak berhasil dikembangkan terutama dalam jangka menengah dan jangka panjang, dapat memberikan dampak-dampak negatif secara keseluruhan terhadap pembangunan nasional. Dampak 
negatif tersebut berupa kesenjangan yang semakin melebar antar wilayah dan antar kelompok tingkat pendapatan masyarakat yang memperlemah fondasi kehidupan sosial, ekonomi, politik dalam masyarakat. Adapun tujuan yang ingin dicapai dari penelitian ini adalah Penelitian ini bertujuan untuk mengetahui kelayakan pemekaran wilayah Bogor Timur dan menyusun strategi pengembangan wilayah berdasarkan potensi ekonomi dan karakteristik wilayah Bogor Timur.

\section{METODE}

Penelitian ini dilaksanakan dengan menggunakan analisis skoring berdasarkan Peraturan Pemerintah no. 78 Tahun 2007 tentang Tata Cara Pembentukan, Penghapusan, Penggabungan Daerah. Yaitu persyaratan administratif, persyaratan teknis dan persyaratan fisik kewilayahan.

1. Persyaratan administratif didasarkan atas aspirasi sebagian besar masyarakat setempat untuk ditindaklanjuti oleh pemerintah daerah dengan melakukan kajian akademis terhadap rencana pembentukan daerah.

2. Persyaratan teknis didasarkan pada faktor kemampuan ekonomi, potensi daerah, sosial budaya, sosial politik, kependudukan, luas daerah pertahanan, keamanan dan faktor lain yang memungkinkan terselenggaranya otonomi daerah. Adapun faktor lain meliputi pertimbangan kemampuan keuangan, tingat kesejahteraan masyarakat dan rentang kendali penyelenggaraan pemerintahan.

3. Sedangkan persyaratan fisik kewilayahan dalam pembentukan daerah meliputi cakupan wilayah, lokasi calon ibukota, sarana dan prasarana pemerintahan

Alat analisis yang lain yang digunakan dalam penelitian ini adalah analisis derajat otonomi fiskal untuk mengetahui kaemampuan fiskal, location quotient (LQ) untuk mengetahu sektor basis, analisis Tipologi Klassen untuk mengidentifikasi tipologi wilayah dan analisis SWOT untuk penentuan strategi pembangunan wilayah. Penelitian dilaksanakan di Kabupaten Bogor dengan fokus analisis terhadap tujuh kecamatan di wilayah Bogor Timur, yaitu Kecamatan Cileungsi, Gunung Putri, Klapanunggal, Jonggol, Sukamakmur, Tanjungsari dan Cariu. Waktu penelitian dilaksanakan mulai bulan Februari 2017 sampai dengan bulan Mei 2017.

\section{Analisis Prospek Pembentukan Calon Daerah Otonom Bogor Timur}

Sebagai pembanding dalam dalam pemberian skor calon daerah otonomi baru pemekaran calon Kabupaten Bogor Timur adalah kabupaten-kabupaten di Propinsi Jawa Barat, namun dipilih disesuaikan dengan karakteristik wilayah Kabupaten Bogor dan faktor yang dinilai. Adapun teknik skoring diuraikan sebagai berikut :

1. Setiap indikator pada masing-masing faktor mempunyai skor dengan skala $1-5$, dimana skor 5 masuk dalam kategori sangat mampu, skor 4 kategori mampu, skor 3 kategori kurang mampu dan skor 1 kategori sangat tidak mampu.

2. Besaran/nilai rata-rata pembanding dan besaran jumlah kuota sebagai dasar untuk pemberian skor : skor 5 apabila nilai indikator $\geq 80 \%$ nilai rata-rata; skor 4 apabila nilai indikator $\geq 60 \%$ nilai rata-rata; skor 3 apabila nilai indikator $\geq 40 \%$ nilai rata-rata;skor 2 apabila nilai indikator $\geq 20 \%$ nilai rata-rata; skor 1 apabila nilai indikator $<20 \%$ nilai ratarata.

Tabel 1 Faktor dan Indikator persyaratan teknis Pembentukan Daerah Otonomi Baru berdasarkan PP No.78 Tahun 2007

\begin{tabular}{lc}
\hline \multicolumn{1}{c}{ FAKTOR } & BOBOT \\
\hline Kependudukan & 20 \\
Kemampuan Ekonomi & 15 \\
Potensi Daerah & 15 \\
\hline
\end{tabular}




\begin{tabular}{lc}
\hline \multicolumn{1}{c}{ FAKTOR } & BOBOT \\
\hline Kemampuan Keuangan & 15 \\
Sosial Budaya & 5 \\
Sosial Politik & 5 \\
Luas Daerah & 5 \\
Pertahanan & 5 \\
Keamanan & 5 \\
Tingkat Kesejahteraan Masyarakat & 5 \\
Rentang Kendali $\quad$ Total & 5 \\
\hline
\end{tabular}

Kelulusan ditentukan oleh total nilai seluruh indikator, dengan kategori sebagai berikut

Tabel 2 : Kategori nilai kelulusan

\begin{tabular}{lcl}
\hline \multicolumn{1}{c}{ Kategori } & Total Nilai Indikator & \multicolumn{1}{c}{ Keterangan } \\
\hline Sangat Mampu & $420 \mathrm{~s} / \mathrm{d} 500$ & Rekomendasi \\
Mampu & $340 \mathrm{~s} / \mathrm{d} 419$ & Rekomendasi \\
Kurang Mampu & $260 \mathrm{~s} / \mathrm{d} \mathrm{339}$ & Ditolak \\
Tidak Mampu & $180 \mathrm{~s} / \mathrm{d} \mathrm{259}$ & Ditolak \\
Sangat Tidak Mampu & $100 \mathrm{~s} / \mathrm{d} \mathrm{179}$ & Ditolak \\
\hline
\end{tabular}

Sumber : PP no.78 Tahun 2007

Usulan pembentukan daerah otonom baru ditolak apabila calon daerah otonom atau induknya (setelah pemekaran) mempunyai total nilai seluruh indikator dengan kategori kurang mampu, tidak mampu dan sangat tidak mampu. Atau perolehan total nilai indikator faktor kependudukan kurang dari 80, faktor kemampuan ekonomi kurang dari 60, faktor potensi daerah kurang dari 60 .

\section{Analisis Derajat Kemandirian Fiskal}

Untuk menganalisis tingkat kemandirian fiskal suatu daerah digunakan alat analisis desentralisasi fiskal, yaitu :

Keterangan :

Proporsi PAD $=\frac{\text { PAD }}{\text { TPD }} \times 100 \%$

$\begin{array}{ll}\text { PAD } & : \text { Pendapatan Asli Daerah } \\ \text { DBH } & : \text { Dana Bagi Hasil Pajak/Bukan Pajak } \\ \text { DAU } & : \text { Dana Alokasi Umum } \\ \text { DAK } & : \text { Dana Alokasi Khusus } \\ \text { TPD } & : \text { Total Penerimaan Daerah (PAD + DBH+DAU+DAK) }\end{array}$

\section{Analisis Komparatif Wilayah}

Untuk menganalisis basis ekonomi suatu wilayah, salah satu teknik yang lazim digunakan adalah kuosien lokasi (location quotient, LQ). Location quotient digunakan untuk mengetahui seberapa besar tingkat spesialisasi sektor-sektor basis atau unggulan (leading sectors). Dalam teknik LQ berbagai peubah (faktor) dapat digunakan sebagai indikator pertumbuhan wilayah, misalnya kesempatan kerja (tenaga kerja) dan produk domestik regional bruto (PDRB) suatu wilayah (Adisasmita, 2005).

Untuk mengetahui potensi aktivitas ekonomi yang merupakan sektor basis dan nonbasis dapat digunakan metode location quotient (LQ), rumusnya adalah sebagai berikut :

$$
L Q=\frac{\frac{x i}{\text { PDRBKec }}}{\text { Xi/PDRB Kab }}
$$


di mana xi PDRB Kec $\mathrm{Xi}$ PDRB Kab nilai sektor i di suatu kecamatan

produk domestik regional bruto kecamatan tersebut Nilai sektor i kabupaten produk domestik regional bruto kabupaten

Nilai LQ berkisar pada angka satu. LQ lebih besar dari satu artinya terjadi relatif konsentrasi pada wilayah yang sedang dianalisis dibanding wilayah lainnnya. Hal ini juga dapat mengindikasikan tentang potensi ekspor ke wilayah lainnya. Hal ini sejalan dengan penelitian Sudarya et al (2013), bahwa Analisis keunggulan komparatif wilayah dilakukan untuk mengidentifikasi sektor ekonomi basis dan non basis sebagai dasar bagi penetapan arahan dan strategi pengembangan kecamatan.

\section{Analisis Tipologi Wilayah}

Menurut Kuncoro (2012), alat analisis tipologi daerah digunakan untuk mengetahui gambaran mengenai pola dan struktur pertumbuhan ekonomi masing-masing daerah. Tipologi daerah pada dasarnya membagi daerah berdasarkan dua indikator utama indikator utama yaitu pertumbuhan ekonomi daerah dan pendapatan per kapita daerah. Dengan menentukan rata-rata pertumbuhan ekonomi sebagai sumbu vertikal dan rata-rata pendapatan per kapita sebagai sumbu horizontal, daerah yang diamati dapat dibagi menjadi empat klasifikasi seperti pada Tabel 3, yaitu daerah cepat maju dan cepat tumbuh (high growth and high income), daerah maju tapi tertekan (high income but low growth), daerah berkembang cepat (high grow but low income), dan daerah relatif tertinggal (low growth and low income). Arifin et al (2013) menggunakan analisis ini untuk mengetahui struktur dan pola pertumbuhan ekonomi wilayah pada kawasan minapolitan di Povinsi Gorontalo dengan menggunakan PDRB per kapita dan laju pertumbuhan ekonomi pada subsektor perikanan.

Tabel 3 Tipologi Wilayah

\begin{tabular}{clll}
\hline PDRB per Kapita (y) & \multicolumn{1}{c}{$(\mathrm{yi}>\mathrm{y})$} & \multicolumn{1}{c}{$(\mathrm{yi}<\mathrm{y})$} \\
\hline Laju Pertumbuhan $(\mathrm{r})$ & Pendapatan tinggi dan & $\begin{array}{l}\text { Pendapatan rendah dan } \\
\text { pertumbuhan tinggi }\end{array}$ \\
$(\mathrm{ri}>\mathrm{r})$ & $\begin{array}{l}\text { Pendapatan tinggi dan } \\
\text { pertumbuhan rendah }\end{array}$ & $\begin{array}{l}\text { Pendapatan rendah dan } \\
\text { pertumbuhan rendah }\end{array}$ \\
\hline
\end{tabular}

Keterangan :

ri : rata-rata laju pertumbuhan ekonomi kecamatan i

$r$ : rata-rata laju pertumbuhan ekonomi Kabupaten Bogor

yi : rata-rata PDRB atas dasar harga konstan kecamatan i

$\mathrm{y}$ : rata-rata PDRB atas dasar harga konstan Kabupaten Bogor

\section{Analisis Strategi Pengembangan Wilayah}

Analisis strategi pengembangan wilayah pada caloan DOB Kabupaten Bogor Timur menggunakan analisis SWOT ( Strength, Weakness, Opportunity dan Threats). Analisis ini didasarkan pada logika yang dapat memaksimalkan kekuatan (strengths) dan peluang (opportunities), namun secara bersamaan dapat meminimalkan kelemahan (weaknesses) dan ancaman (threats). Dengan strategi ini daerah dapat mengidentifikasi faktor-faktor strategis daerah yaitu berbagai kondisi pada lingkungan eksternal dan internal yang secara strategik berpengaruh terhadap keberhasilan daerah. Menurt David dan David (2012), teknik formulasi strategi dapat diintegrasikan ke dalam tiga tahapan pengambilan keputusan. Tahap pertama yaitu tahapan input (the input stage) merupakan tahapan pengumpulan 
informasi awal yang diperlukan untuk menyusun starategi. Tahapan kedua adalah tahapan penyesuaian (the matching stage), tahapan ini fokus untuk membangun strategi yang layak berdasarkan faktor internal dan faktor eksternal yang telah diidentifikasi, penyusunan matrik SWOT ada pada tahapan ini. Tahapan ketiga adalah tahapan pengambilan keputusan (the decision stage. Tahapan penyusunan analisis SWOT dapat diuraikan sebagai berikut :

1. Membuat daftar peluang eksternal yang dimiliki daerah

2. Membuat daftar ancaman eksternal yang dimiliki daerah

3. Membuat daftar kekuatan internal yang dimiliki daerah

4. Membuat daftar kelemahan internal yang dimiliki daerah

5. Berdasarkan poin 1 - 4 akan dapat dirumuskan strategi umum (Grand Strategy) strategi alternatif (alternative strategy) melalui SWOT.

\section{HASIL DAN PEMBAHASAN}

\section{Analisis Prospek Pembentukan Calon Daerah Otonom Bogor Timur}

\section{Persyaratan Administratif}

Analisis terhadap persyaratan administratif dilakukan dengan wawancara dengan DPRD Kabupaten Bogor, Sekretariat Daerah Kabupaten Bogor, Bappedalitbang Kabupaten Bogor. Sesuai dengan persyaratan pada PP. No. 78 Tahun 2007 tentang tata cara Pembentukan, Penghapusan, dan Penggabungan Daerah didapatkan hasil sebagai berikut :

1. Pemerintah Daerah Kabupaten Bogor sedang melakukan kajian tentang potensi pemekaran Bogor Timur, hasil kajian tersebut merupakan dasar rekomendasi pembentkan calon daerah otonom Bogor Timur.

2. Belum ada keputusan DPRD Kabupaten Bogor, Bupati Bogor, DPRD Provinsi Jawa Barat, dan Gubernur Jawa Barta tentang persetujuan pembentukan calon daerah otonom Bogor Timur.

\section{Persyaratan Teknis}

Syarat teknis yang dianalisis meliputi faktor kependudukan, kemampuan ekonomi, potensi daerah, kemampuan keuangan, sosial budaya, sosial politik, luas daerah, pertahanan, keamanan, tungkat kesejahteraan masyarakat, dan rentang kendali. Berikut ini diuraikan hasil analisis skoring terhadap penilaian persyaratan pembentukan daerah otonom baru:

Tabel 4 Hasil Analisis Kelayakan Teknis Bogor Timur

\begin{tabular}{llcc}
\hline No & Faktor & Nilai Bogor Timur & Keterangan \\
\hline 1. & Kependudukan & 100 & Nilai Minimal 80 \\
2. & Kemampuan Ekonomi & 75 & Nilai Minimal 60 \\
3. & Potensi daerah & 60 & Nilai Minimal 60 \\
4. & Kemampuan Keuangan & 75 & Nilai Minimal 60 \\
5. & Sosial Budaya & 25 & - \\
6. & Sosial Politik & 25 & - \\
7. & Luas Daerah & 10 & - \\
8. & Pertahanan & - & Tidak ada data \\
9. & Keamanan Kesejahteraan & - & Tidak ada data \\
10. & Tingkat & 25 & - \\
& Masyarakat Kendali & & - \\
\hline
\end{tabular}

Berdasarkan hasil analisis, calon daerah otonomi baru Kabupaten Bogor Timur memiliki nilai 420, yang berarti secara kumulatif calon daerah otonom masuk pada kategori sangat mampu untuk menyelenggarakan otonomi daerah. Nilai yang diperoleh keempat faktor dominan yaitu faktor kependudukan, faktor kemampuan ekonomi, faktor potensi 
daerah dan faktor kemampuan keuangan memenuhi persyaratan minimal sehingga berdasarkan analisis skoring, persyaratan kelayakan teknis dapat terpenuhi, walaupun ada data yang belum lengkap. Untuk faktor dominan yaitu faktor kependudukan, kemampuan ekonomi, potensi daerah dan kemampuan keuangan nilainya telah memenuhi syarat minimal yaitu $80 \%$ dari nilai faktor. Nilai faktor kependudukan 100 (100\%), faktor kemampuan ekonomi 75 (100\%), faktor potensi daerah $60(80 \%)$ dan faktor kemampuan keuangan $75(100 \%)$.

\section{Persyaratan Fisik Kewilayahan}

Cakupan wilayah dalam pembentukan sebuah kabupaten paling sedikit 5 (lima) kecamatan yang bergabung. Terdapat 7 (tujuh) kecamatan yang termasuk dalam rencana pembentukan calon daerah otonom Bogor Timur yaitu Kecamatan Sukamakmur, Cariu, Tanjungsari, Jonggol, Cileungsi, Klapanunggal dan Gunung Putri. Dengan demikian cakupan wilayah calon daerah otonom Bogor Timur telah memenuhi syarat pembentukan sebuah daerah otonom

\section{Analisis Kemandirian Fiskal}

Untuk mengetahui kapasitas keuangan suatu daerah dapat digunakan analisis kemampuan fiskal berdasarkan potensi pendapatan daerah. Berikut ini diuraikan potensi pendapatan Bogor Timur berdasarkan pendapatan Kabupaten Bogor 2016 yang terdiri dari Pendapatan Asli Daerah (PAD), Dana Alokasi Umum (DAU), Dana Bagi Hasil (DBH) dan Dana Alokasi Khusus (DAK). Data PAD berdasarkan proporsi dari pajak daerah masingmasing wilayah. DAU dihitung proporsional dengan memperhitungkan jumlah penduduk dan luas wilayah, DBH dihitung proporsional sesuai pendapatan masing-masing wilayah dan DAK dihitung berdasarkan alokasi DAK fisik masing-masing wilayah Tahun 2016.

Tabel 2 Perbandingan pendapatan daerah berdasarkan wilayah pengembangan

\begin{tabular}{llll}
\hline \multirow{2}{*}{ Sumber Pendapatan Daerah (Rp) } & Bogor Timur & Bogor Tengah & Bogor Barat \\
\hline Pendapatan Asli Daerah & $427,115,466,598$ & $960,793,522,902$ & $133,017,785,377$ \\
Dana Alokasi Umum & $421,911,651,480$ & $796,779,008,613$ & $699,608,837,464$ \\
Dana Bagi Hasil & $75,238,024,079$ & $169,247,456,166$ & $23,431,591,974$ \\
Dana Alokasi Khusus & $26,186,217,000$ & $39,459,549,000$ & $71,657,875,000$ \\
\hline \multicolumn{1}{c}{ Jumlah } & $950,451,359,157$ & $1,966,279,536,681$ & $927,716,089,816$ \\
\hline
\end{tabular}

Sumber : Badan Pengelolaan Pendapatan Daerah Kabupaten Bogor 2016 (diolah)SKPD terkait (diolah)

Analisis terhadap kemampuan fiskal menjadi hal yang sangat penting dalam pemekaran daerah. Peraturan Pemerintah No. 78 Tahun 2007 menjadikan faktor kemampuan ekonomi dan kemampuan keuangan menjadi salah satu faktor dominan yang harus dipenuhi dalam persyaratan teknis pemekaran daerah. Juanda et al (2012) menyebutkan bahwa dalam pembentukan sebuah daerah otonomi baru kedua faktor tersebut seringkali diabaikan dalam penilaian awal pemekaran daerah. Undang-undang penetapan daerah otonomi baru yang tidak mengindahkan Peraturan Pemerintah Tentang Tata Cara Pembentukan, Penghapusan dan Pembentukan Daerah menjadi salah satu penyebab gagalnya daerah otonomi baru dalam memberikan pelayanan yang berkualitas dan meningkatkan kesejahteraan masyarakat. 
Menurut Sijabat et al (2015), mengukur kemampuan keuangan daerah dapat dilihat dari derajat rasio otonomi fiskal (DOF). Derajat otonomi fiskal dapat diukur dengan cara perhitungan sebagai berikut :

$$
\text { DOF }=\frac{\text { Pendapatan Asli Daerah }(P A D)}{\text { Total } \text { Pendapatan Daerah }} \times 100
$$

Tolok ukur kemampuan keuangan daerah ditunjukkan dalam skala interval DOF sebagai berikut :

Tabel 3 : Interval derajat otonomi fiskal

\begin{tabular}{ll}
\hline PAD/TPD (\%) & Kemampuan Keuangan \\
\hline $0.00-10.00$ & Sangat kurang \\
$10.00-20.00$ & Kurang \\
$20.01-30.00$ & Sedang \\
$30.01-40.00$ & Cukup \\
$40.01-50.00$ & Baik \\
$>50.01$ & Sangat Baik \\
\hline
\end{tabular}

Sumber : Sijabat, 2015

Berdasarkan data tersebut dapat dihitung derajat otonomi fiskal untuk Bogor Timur adalah sebagai berikut :

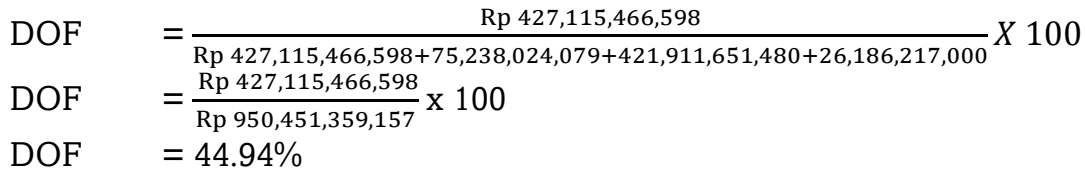

Dari hasil analisis Derajat Otonomi Fiskal diketahui bahwa Bogor Timur termasuk pada kategori Derajat Otonomi Fiskal "Baik" yang berarti Bogor Timur memiliki kemampuan keuangan yang baik untuk menyelenggarakan pemerintahan sendiri. Kemandirian fiskal merupakan persyaratan penting dalam pelaksanaan otonomi daerah melalui desentralisasi. Suatu daerah dikatakan mampu untuk melaksanakan otonomi daerah salah satu cirinya terletak pada kemandirian keuangan daerah. Dengan kata lain daerah otonom harus memiliki kewenangan dan kemampuan untuk menggali sumber-sumber keuangan sendiri, mengelola dan menggunakan keuangan sendiri yang cukup memadai untuk membiayai penyelenggaraan pemerintahan sendiri (Rinaldi, 2012).

\section{Analisis Komparatif Wilayah}

Analisis dilakukan terhadap Produk Domestik Daerah Bruto (PDRB) Kabupaten Bogor tahun 2015. Produk Domestik Regional Bruto merupakan salah satu indikator makro pembangunan ekonomi di suatu wilayah. Hasil analisis LQ ketujuh kecamatan wilayah pengembangan Bogor Timur disajikan pada Tabel 4.

Tabel 4 Nilai LQ kecamatan di wilayah pengembangan Bogor Timur Tahun 2015

\begin{tabular}{|c|c|c|c|c|c|c|c|}
\hline \multirow[b]{2}{*}{ Sektor } & \multicolumn{7}{|c|}{ Kecamatan } \\
\hline & $\begin{array}{l}\text { Suka } \\
\text { makmur }\end{array}$ & Cariu & Tanjungsari & Jonggol & Cileungsi & Klapanunggal & $\begin{array}{l}\text { Gunung } \\
\text { Putri }\end{array}$ \\
\hline Primer & & & & & & & \\
\hline Pertanian & 15.88 & 3.78 & 9.83 & 4.05 & 0.05 & 0.36 & 0.02 \\
\hline $\begin{array}{l}\text { Pertambangan \& } \\
\text { Penggalian }\end{array}$ & 0.12 & 0.23 & 0.23 & 0.48 & 0.02 & 1.84 & 0.00 \\
\hline
\end{tabular}




\begin{tabular}{|c|c|c|c|c|c|c|c|}
\hline \multirow[b]{2}{*}{ Sektor } & \multicolumn{7}{|c|}{ Kecamatan } \\
\hline & $\begin{array}{l}\text { Suka } \\
\text { makmur }\end{array}$ & Cariu & Tanjungsari & Jonggol & Cileungsi & Klapanunggal & $\begin{array}{l}\text { Gunung } \\
\text { Putri }\end{array}$ \\
\hline Sekunder & & & & & & & \\
\hline $\begin{array}{l}\text { Industri } \\
\text { Pengolahan }\end{array}$ & 0.04 & 0.07 & 0.16 & 0.06 & 1.46 & 1.57 & 1.16 \\
\hline $\begin{array}{l}\text { Listrik, Gas \& Air } \\
\text { Bersih } \\
\text { Tersier }\end{array}$ & 2.96 & 1.72 & 2.74 & 1.42 & 0.65 & 0.27 & 0.53 \\
\hline Konstruksi & 0.04 & 0.27 & 0.04 & 0.81 & 0.79 & 0.40 & 0.34 \\
\hline $\begin{array}{l}\text { Perdagangan, } \\
\text { Hotel \& Restoran }\end{array}$ & 1.01 & 3.13 & 1.56 & 2.79 & 0.36 & 0.13 & 1.04 \\
\hline $\begin{array}{l}\text { Pengangkutan \& } \\
\text { Komunikasi }\end{array}$ & 0.21 & 0.52 & 0.78 & 0.87 & 0.14 & 0.06 & 1.83 \\
\hline $\begin{array}{l}\text { Keuangan, } \\
\text { Persewaan, \& } \\
\text { Jasa Perusahaan }\end{array}$ & 0.21 & 0.91 & 0.57 & 1.03 & 1.06 & 0.68 & 0.32 \\
\hline Jasa-Jasa & 1.43 & 1.51 & 2.08 & 2.56 & 0.66 & 0.17 & 0.38 \\
\hline
\end{tabular}

Sumber : Bappeda Kabupaten Bogor dan BPS Kabupaten Bogor, 2016 (diolah)

Secara umum Kecamatan Sukamakmur, Cariu, Tanjungsari dan Jonggol masih mengandalkan basis ekonominya pada kelompok sektor primer yaitu Pertanian. Kecamatan Sukamakmur dengan LQ yang sangat tinggi pada sektor pertanian yaitu 15.88, Cariu 3.78, Tanjungsari 9.83 dan Jonggol 4.05. Sub Wilayah Pengembangan Cileungsi yaitu Kecamatan Gunung Putri, Cileungsi dan Klapanunggal unggul pada sektor sekunder yaitu Industri Pengolahan. Kecamatan Cileungsi dengan nilai LQ 1.46, Klapanunggal 1.57 dan Gunung Putri 1.16. Adapun pada sektor primer hanya unggul pada satu kecamatan yaitu Klapanunggal, itupun terbatas pada subsektor Pertambangan dan Galian.

\section{Analisis Tipologi Wilayah}

Kriteria yang digunakan untuk membagi wilayah kecamatan dalam penelitian ini adalah sebagai berikut : (1) daerah cepat maju dan cepat tumbuh yaitu daerah yang memiliki tingkat pertumbuhan ekonomi dan pendapatan per kapita lebih tinggi daripada rata-rata Kabupaten Bogor; (2) daerah maju tapi tertekan yaitu daerah yang memiliki pendapatan per kapita lebih tinggi tetapi tingkat pertumbuhan ekonomi lebih rendah daripada rata-rata Bogor Timur;(3) daerah yang berkembang cepat, yaitu daerah yang memiliki tingkat pertumbuhan tinggi tetapi pendapatan per kapita lebih rendah daripada rata-rata Bogor Timur; (4) daerah relatif tertinggal adalah daerah yang memiliki tingkat pertumbuhan ekonomi dan pendapatan per kapita lebih rendah daripada rata-rata Wilayah Bogor Timur. Adapun data pendapatan per kapita dan tingkat pertumbuhan ekonomi untuk 7 kecamatan di wilayah Bogor Timur dapat dilihat pada Tabel 5.

Tabel 5 PDRB Per Kapita Harga Konstan Tahun 2010 dan Pertumbuhan Ekonomi Tahun 2015 Wilayah Bogor Timur

\begin{tabular}{lcr}
\hline \multicolumn{1}{c}{ Wilayah } & Laju Pertumbuhan Ekonomi (\%) & PDRB per Kapita (Rupiah) \\
\hline Kecamatan Sukamakmur & -0.94 & $2,107,667$ \\
Kecamatan Cariu & 8.58 & $4,119,595$ \\
Kecamatan Tanjungsari & 4.22 & $2,551,596$ \\
Kecamatan Jonggol & 9.62 & $2,667,376$ \\
Kecamatan Cileungsi & 5.13 & $20,026,636$ \\
Kecamatan Klapanunggal & 5.44 & $28,501,712$ \\
Kecamatan Gunung Putri & 6.10 & $25,485,502$ \\
Rata-rata Bogor Timur & 5.45 & $12,208,583.43$ \\
\hline
\end{tabular}


Dari data pendapatan per kapita dan pertumbuhan ekonomi dapat membagi wilayah kecamatan menjadi 4 kategori sesuai dengan Tipologi Klassen. Dengan menggunakan analisis ini dapat diketahui corak atau kondisi perekonomian suatu wilayah. Tipologi Klassen pada dasarnya membagi wilayah berdasarkan dua indikator utama yaitu PDRB per kapita dan laju pertumbuhan ekonomi (LPE). Dalam analisis ini digunakan PDRB per kapita 7 kecamatan di wilayah Bogor Timur atas dasar harga konstan tahun 2010, laju pertumbuhan ekonomi 7 kecamatan wilayah Timur 2015 dibandingkan terhadap LPE dan PDRB per kapita rata-rata wilayah Timur . Tipologi wilayah Bogor Timur dapat dilihat pada Gambar 1.

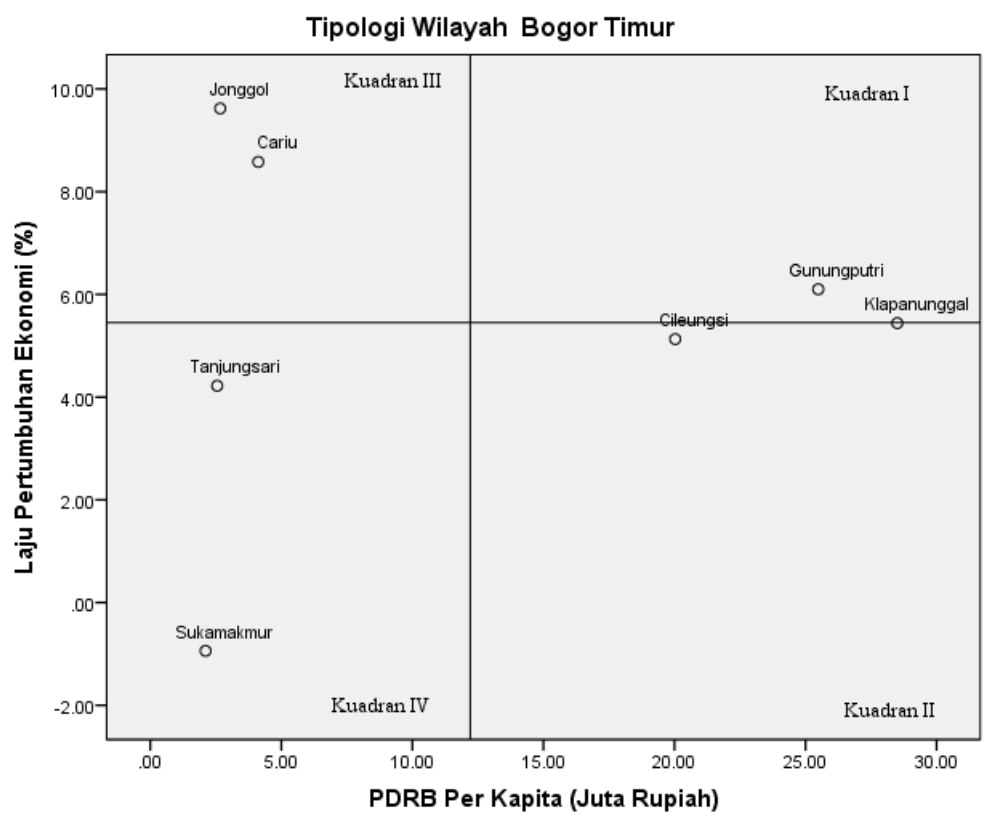

Gambar 1. Tipologi Wilayah Bogor Timur

Kecamatan Gunung Putri, termasuk ke dalam klasifikasi daerah maju (high income high growth), yaitu daerah dengan Lapju Pertumbuhan Ekonomi dan pendapatan per kapita yang lebih tinggi dibanding rata-rata Wilayah Bogor Timur. Kecamatan Klapanunggal dengan pertumbuhan ekonomi 5.44 hampir masuk kategori daerah maju. Dua kecamatan yaitu Jonggol dan Cariu masuk pada klasifikasi daerah yang berkembang cepat (high growth but low income), sedangkan dua kecamatan lainnya yaitu Tanjungsari dan Sukamakmur termasuk pada klasifikasi daerah relatif tertinggal (low growth low income). Kecamatan Cileungsi termasuk pada klasifikasi daerah maju tetapi tertekan. Hal ini menunjukkan bahwa Kecamatan Cileungsi memiliki pendapatan per kapita tinggi tetapi tingkat pertumbuhan ekonomi lebih rendah dibanding rata-rata wilayah Bogor Timur

\section{Analisis Strategi Pengembangan Wilayah}

Strategi pengembangan wilayah untuk Wilayah Pengembangan Timur merupakan hasil kajian terhadap literatur dan studi pustaka yang diperoleh dari BPS Kabupaten Bogor, 


\section{Bappedalitbang Kabupaten Bogor dan Peraturan Daerah Kabupaten Bogor No. 11 Tahun 2016 tentang Rencana Tata Ruang Wilayah Kabupaten Bogor Tahun 2016-2036. \\ Tabel 6 Matriks Analisis SWOT}

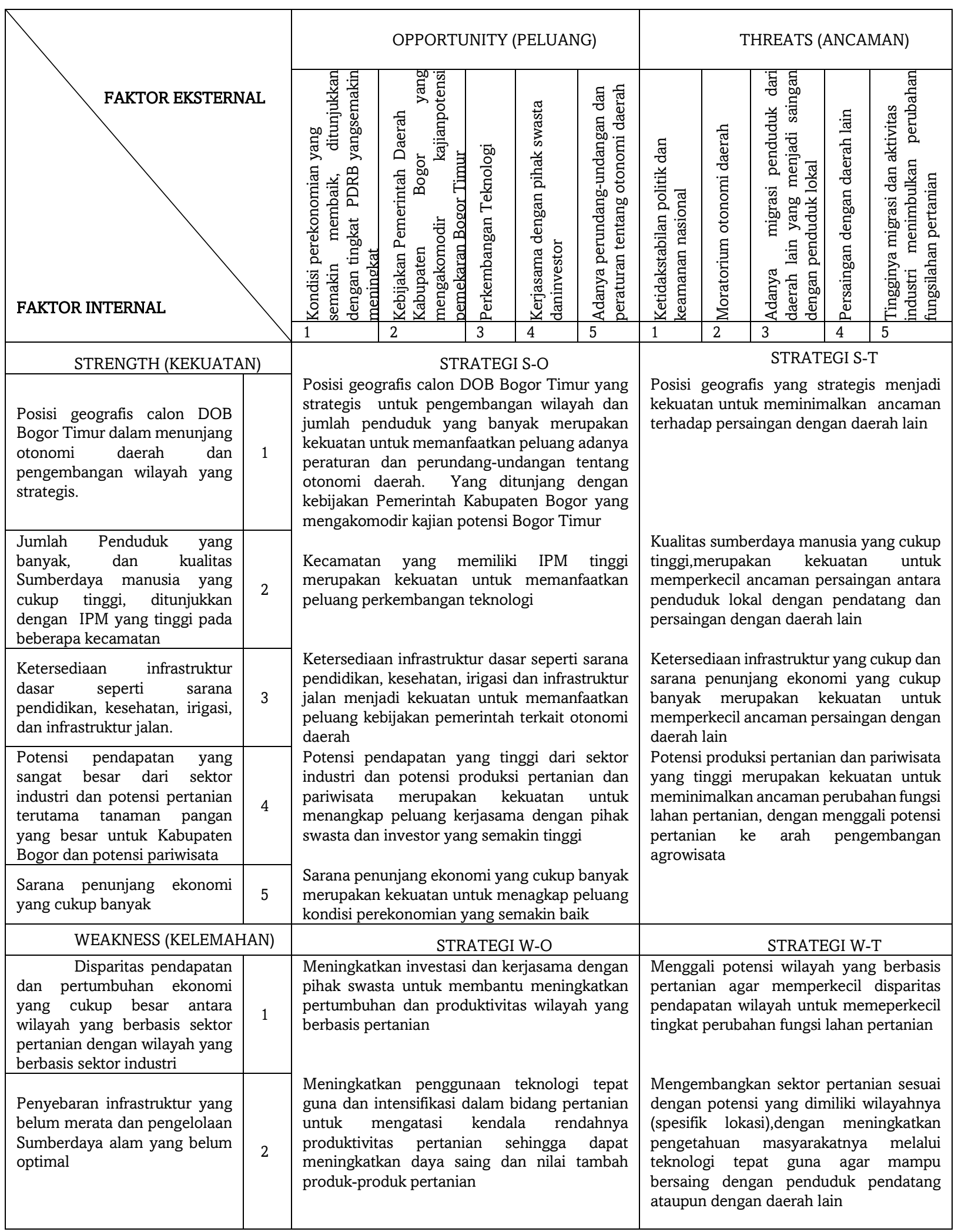


Berdasarkan hasil analisis, jika dikaitkan dengan analisis LQ terlihat bahwa daerah yang termasuk kelompok daerah maju adalah daerah yang struktur ekonominya didominasi oleh sektor industri pengolahan. Sedangkan kelompok daerah yang termasuk kategori daerah relatif tertinggal merupakan daerah yang struktur ekonominya didominasi oleh sektor pertanian. Demikian juga dengan melihat analisis skalogram, daerah yang termasuk kategori maju seperti Gunung Putri, Cileungsi dan Klapanunggal adalah daerah yang termasuk pada kategori Hirarki I, yaitu daerah yang diidentifikasi sebagai pusat pertumbuhan untuk wilayah Bogor Timur. Strategi pengambangan wilayah hendaknya disesuaikan dengan karakteristik masing-masing wilayah yang disesuaikan dengan rencana struktur ruang dan rencana pola ruang seperti yang telah ditetapkan dalam Perda No. 11 Tahun 2016 Tentang RTRW Kabupaten Bogor Tahun 2016-2036. . Berdasarkan data-data tersebut disusun faktor internal dan faktor eksternal analisis SWOT secara kualitatif terkait pengembangan wilayah Bogor Timur seperti tercantum pada Tabel 6.

Berdasarkan matriks analisis SWOT, maka strategi pengembangan wilayah yang dapat diterapkan adalah :

1. Menciptakan situasi yang kondusif untuk meningkatkan kerjasama dengan investor atau pihak swasta.

2. Meningkatkan kualitas sumberdaya manusia dan penguasaan teknologi agar dapat memanfaatkan sumberdaya alam secara optimal.

3. Pemerataan infrastruktur untuk mengurangi ketimpangan baik dari segi pendapatan maupun IPM.

4. Mengembangkan sektor pertanian pada wilayah yang struktur ekonominya dengan peningkatan penggunaan teknologi untk meningkatkan produktivitas dan nilai tambah produk-produk pertanian.

5. Kebijakan pemerintah daerah untuk mengoptimalkan pemanfaatan potensi sumberdaya yang ada untuk pengembangan kawasan agroindustri dan agrowisata.

\section{KESIMPULAN}

Hasil analisis kelayakan teknis dan fisik kewilayahan menunjukkan Bogor Timur layak untuk menjadi sebuah daerah otonom, akan tetapi syarat Kelayakan administratif belum terpenuhi. Bogor Timur termasuk pada kategori Derajat Otonomi Fiskal Baik.Strategi pengembangan wilayah yang sesuai untuk Bogor Timur adalah dengan meningkatkan pengembangan potensi pertanian pada SWP Jonggol, dan meningkatkan sektor industri pengolahan pada SWP Cileungsi.

Walaupun berdasarkan analisis persyaratan teknis Bogor Timur termasuk kategori mampu untuk menyelenggarakan otonomi daerah, namun perlu dipertimbangkan bahwa pemekaran berdampak terhadap beban fiskal baik pemerintah pusat maupun kabupaten induk karena pengeluaran pemerintah meningkat akibat pembentukan daerah otonom baru. Bogor Timur termasuk pada kategori Derajat Otonomi Fiskal Baik, kemampuan fiskal pada suatu daerah merupakan suatu syarat agar daerah mampu menyelenggarakan pemerintahan. Untuk meningkatkan Pendapatan Asli Daerah, perlu diupayakan kebijakankebijakan pemerintah yang dapat mendukung pemanfaatan potensi sumberdaya alam yang tersedia. Pemerintah daerah perlu menciptakan situasi yang kondusif dalam peningkatan investasi dalam upaya meningkatkan pertumbuhan ekonomi dan produktivitas daerah. Karakter yang berbeda pada subwilayah pengembangan diharapkan pemerintah daerah mampu mengembangkan sektor-sektor yang menjadi unggulan untuk masing-masing subwilayah pengembangan sesuai dengan karakteristiknya. Wilayah yang memiliki struktur ekonomi relatif baik adalah Kecamatan Gunung Putri, Klapanunggal dan Cileungsi. Ketiga kecamatan tersebut memiliki PDRB per kapita di atas rata-rata Kabupaten Bogor. Sedangkan 
Kecamatan Sukamakmur dan Tanjungsari termasuk pada kategori daerah relatif tertinggal (low income low growth). Hal ini merupakan gambaran terjadinya kesenjangan pertumbuhan ekonomi antar kecamatan di Wilayah Bogor Timur, sehingga membutuhkan kebijakan dari pemerintah terkait pengembangan wilayah di daerah tersebut. Pemerintah perlu meningkatkan peran sektor yang sesuai dengan karakter dan potensi sumberdaya alam di wilayah Kecamatan Sukamakmur dan Tanjungsari.

\section{DAFTAR PUSTAKA}

Adisasmita, R. 2005. Dasar-dasar Ekonomi Wilayah. Cetakan Pertama. Yogyakarta : Graha Ilmu.

Arifin, T., Terry L. Kepel dan S. N. Amri. 2013. Analisis Tipologi Wilayah Dalam Mendukung Pengembangan Minapolitan di Propinsi Gorontalo. Jurnal Tataloka Volume 15 No.2:129-139.

Bappeda Kabupaten Bogor bekerja sama dengan BPS Kabupaten Bogor. 2016. PDRB Menurut Skala Usaha dan Kecamatan di Kabupaten Bogor Tahun 2015. Bappeda Kabupaten Bogor.

Juanda, B. dan Masrizal. 2012. Pembentukan Daerah Otonomi Baru (DOB) : Tinjauan Dari Aspek Keuangan. Policy Brief 2012. Kementerian Keuangan Republik Indonesia Direktorat Jenderal Perimbangan Keuangan. Jakarta:Hal 41-49.

Kementerian Dalam Negeri. 2014. Pembentukan Daerah-daerah Otonom di Indonesia Sampai Dengan Tahun 2014.

Kemitraan. 2012. Parameter Daerah Persiapan Penjelasan Teknis Pembentukan Daerah Otonom Baru dalam Desain Besar Penataan Daerah. Kemitraan Bagi Pembaruan Tata Pemerintahan. Jakarta.

Kuncoro, M. 2004. Otonomi dan Pembangunan Daerah : Reformasi, Perencanaan, Strategi dan Peluang. Jakarta: Erlangga.

Rinaldi, U. 2012. Kemandirian Keuangan dalam Pelaksanaan Otonomi Daerah. Jurnal Eksos Volume 8 No.2:105-113.

Rustiadi, E. A. Anwar, dan D.O.Pribadi. 2003. Sistem Perencanaan Pembangunan dalam Era Reformasi dan Otonomi Daerah. Seminar Menuju Perencanaan Pada Era Masyarakat Madani. 28 Juli 2003.

Sijabat, M.Y. C. Saleh, dan A. Wachid. 2015. Analisis Kinerja Keuangan Serta Kemampuan Keuangan Pemerintah Daerah Dalam Pelaksanaan Otonomi Daerah (Studi Pada Dinas Pendapatan Daerah dan Badan Pengelola Keuangan dan Aset Daerah Kota Malang Tahun Anggaran 2008 - 2012). Jurnal Administrasi Publik (JAP). Volume 2 N0.2 :236-242.

Sjafrizal. 2012. Ekonomi Wilayah dan Perkotaan. Cetakan ke-1. Jakarta : Rajawali Pers.

Sudarya, D. Santun R.P. Sitorus, dan M. Firdaus. 2013. Analisis Perkembangan Ekonomi Wilayah Untuk Arahan Pembangunan Kecamatan di Wilayah Pesisir Kabupaten Garut. Jurnal Ilmiah Geomatika. Volume 19 No. $2: 134-140$.

Supriyadi, Amandelis dan S. Rahmadi. 2013. Anaisis Desentralisasi Fiskal di Kabupaten Bungo. Jurnal Pembiayaan dan Pembangunan Daerah. Volume 1 No.1:1-10.

Susanti. 2014. Dampak Pemekaran Wilayah Terhadap Kesejahteraan di Kabupaten Lampung Utara. Jurnal Ekonomi Pembangunan. Vol 3 No. 2: 249 - 267.

Tarigan, R. 2012. Perencanaan Pembangunan Wilayah. Cetakan keenam. Jakarta : Bumi Aksara.

Wardhana, A., B. Juanda, H. Siregar, dan K. Wibowo. 2013. Dampak Transfer Pemerintah Pusat Terhadap Ketimpangan Pendapatan di Indonesia. Sosiohumaniora Volume 15 No.2: $111-118$. 